\title{
Entrepreneurial Intention: Does Entrepreneurial Education Matter in Pakistan?
}

\author{
Temoor Anjum \\ Post Graduate Center, Limkokwing University of Creative Technology, \\ Cyberjaya, Selangor, Malaysia \\ Dr. Sara Ravan Ramzani \\ Post Graduate Center, Limkokwing University of Creative Technology, \\ Cyberjaya, Selangor, Malaysia
}

Nida Nazar

Post Graduate Center, Limkokwing University of Creative Technology, Cyberjaya, Selangor, Malaysia

Imran Ahmed Shahzad (Corresponding Author)

Post Graduate Center, Limkokwing University of Creative Technology, Cyberjaya, Selangor, Malaysia

Shahrukh Salman

Post Graduate Center, Limkokwing University of Creative Technology, Cyberjaya, Selangor, Malaysia

Received: May 28, 2018 Accepted: June 22, 2018 Online published: July 5, 2018 doi:10.5296/ijhrs.v8i3.13213 URL: https://doi.org/10.5296/ijhrs.v8i3.13213 


\section{Abstract}

The purpose of this study is to investigate the association between entrepreneurial intention and entrepreneurial education. Data were collected with the help of a structure questionnaire; a total 595 responses were collected back. SmartPLS was used to test the hypothesized relationship. The findings showed that entrepreneurial intentions are strongly and positively related to entrepreneurial education.

Keywords: entrepreneurial intention, satisfaction, development, entrepreneurial intentions

\section{Introduction}

The importance of entrepreneurship in economic development can never be underestimated. This is because it plays a crucial role in the development of the Micro and Macroeconomic. Policy makers, researchers and renowned Economists have attested to the fact that entrepreneurship plays a vital role in economy development. In the words of Schumpeter (1951), on a macro level "entrepreneurship rejuvenates economies, boosts innovations in the industries, and introduces more effective and efficient means of production and a vibrant force behind the development of any economy". Also, on a micro point of view, entrepreneurship provides opportunity to the perceived less vibrant groups to contribute their talents and efforts towards economic development (Autio \& Acs 2010). According to O'Connor (2013), there is an increasing trend for government policy to promote entrepreneurship due to its economic benefit. Gibb (2002a) keys into the idea that international and national benefits will be gained from active participation in entrepreneurship. According to Gartner 1988, "Entrepreneurship is commonly associated with business creation and it involves the process of getting into and operating someone's own business". Entrepreneurship is the most essential component in wealth production, job creation, innovation and socio-economic development (Keat, Selvarajah \& Meyer (2011)).

Over the years, efforts have been made to promote entrepreneurship among youths and university graduates. This is due to the importance of entrepreneurship in structural and behavioral changes. Measures have been made to support entrepreneurship by policy makers and the most important among these measures is the call for academia to reconsider their role as promoters and entrepreneurial ventures (Liñán, Urbano \& Guerrero 2011); Heinonen \& Poikkijoki, 2006). According to Koe, Sa'ari, Majid, \& Ismail (2012). educational institutions, especially universities, are encouraged to contribute through a specific education program: business education. The phenomenon of business education has been adopted by many university courses. This is because they understand its importance for economic development. According to Fayolle \& Gailly, 2004; Lin, Lin, \& Lin (2010).) "The objectives of these developments and initiatives are especially focused on exploring and developing the unexplored strengths of universities and research institutions. The content of these courses is designed to promote the entrepreneurial attitude and culture of graduates They allow them to start their own business (Otsuki, M. (2002). According to Katz, 2003, Kuratko, 2005) business education has a relatively long history and has become a universal phenomenon. Several early studies have documented remarkable growth rate and development in entrepreneurship developments' curriculum. However, the number of universities and 
colleges offering entrepreneurship courses and programs has grown from few in 1970s to thousands around the world (Naffziger, Hornsby \& Kuratko, 1994).

In the $21^{\text {st }}$ century, several universities are offering entrepreneurship as major, minors, certificates, diplomas and master degrees. As part of the effort to further strengthen this discipline, some high research-oriented universities are offering $\mathrm{PhD}$ programs in research to build its teaching strength in entrepreneurship (Kuratko, D. F. 2003). Entrepreneurship has grown faster than any other field of study in the last forty years. The pace in entrepreneurship is really growing rapidly as more universities are passionately striving towards developing entrepreneurship programs and courses. Kuratko (2005) stated that "Entrepreneurship is new and is about continuous innovation and creativity. It is the future of business schools and it should begin to move into leadership role". It will not be out of place to say that entrepreneurship programs have become very relevant among universities and school of businesses.

\section{Problem Statement}

It is so painful that business start-ups and entrepreneurship activities in Pakistan are underperforming compare to other countries. Irrespective of the efforts made to develop entrepreneurship, the results are still unimpressive. The sum of early entrepreneurial activity or TEA rate in Pakistan (the rate of new entrepreneurs and new business managers) is $9.07 \%$. This is lower than the average rate of TEA of the economy driven by factors $(4.22 \%)$ and the economy driven by efficiency (13.8\%) (Coduras, Urbano, Rojas \& Martínez, 2008). According to Akbar \& Bashir, "the Pakistani government can see the initial entrepreneurial and start-up activities of low-level enterprises through two different policy approaches." First, as early as the 1970s and 1980s, Pakistani political leaders shared their points. of view on entrepreneurship, is the investment in the industrial level on a large scale. As part of the effort to make entrepreneurship activities booming in Pakistan, policy makers have adopted approaches that will help to attract investment. Some of the approaches adopted are; subsidizing credits for investors, licensing monopolies for protected markets, inputs for certain activities and above all emphasizing on large scale manufacturing rather than SME. This has led to increase in challenging economic and socio-cultural business environment for entrepreneurship to strive (Shook, \& Bratianu, (2010). Going the economic definition, it will not be out of place for one to say that entrepreneurship in Pakistan is very weak and prejudiced by government policies, legislation and regulation. This is why all efforts by entrepreneurs and startups to strive competitively in Pakistan environment don't yield the desired results (Shaikh, D. M. 2012).

Secondly, in the last 10 years, stakeholders in the education's sector including policy agencies and higher institution have been striving towards inculcating entrepreneurial behavior and skills among university graduates. However, they have been massive failure in an attempt to develop the requisite skills needed to impart entrepreneurial attitudes among students (Shaikh, D. M. 2012). The 2007 SME policy in Pakistan stated that "the development of entrepreneurship among university graduates lacks a coherent policy framework that determines the role of all the respective stakeholders in their particular domains". It is 
important to note here that the efforts that have been tailored towards entrepreneurship have been based on personality and entrepreneurial psychology literatures. These literatures' explanation of business creation is not reliable as experts have questioned the authenticity of the definition. In view of this, there is an urgent need to critically $x$-tray the current strategies that are adopted to promote entrepreneurship education. Also analysis should be done on how youths leaving schools, college and universities view entrepreneur and their level of commitment to business and jobs creation. The current research and studies carried out on entrepreneurship development focus more on the problem statement. This will enable Economists and policy makers identify the roles of educational factors in ensuring the success of entrepreneurship policies and program in Pakistan.

\section{Entrepreneurial Education and Entrepreneurial Students}

Institutions of learning in Pakistan are saddled with the responsibility of properly inculcate in their students motivating spirit, knowledge, skills and capabilities to create a venture. This task is mostly described as the third mission of universities; this will make the students to imbibe the value of discipline-specific teaching and research (Gibb, 1993; Brown, R. B., 2000; Johannisson, Halvarsson, \& Lōvstal, 2001). Some of the early debates on entrepreneurship looked into the extent to which formal education was likely affect the motivation, capacity as well as success of entrepreneurship. During the debate most authors were of the opinion that formal education has failed to inculcate the hunger to create a venture or business establishment culture on university students. According to them, formal education has become counterproductive as it is only equipping students with knowledge that will make them job seekers rather than jobs creators (Timmons 1999). This will only promote wage earning mentality and over dependence of government for job creation (Kourilsky \& Walstad, 1998). Further to this, If nothing is done about this, creativity, innovation and entrepreneurship activities will dwindle drastically; "previous demographic studies revealed that entrepreneurs have less education than other people in the working population, but this view is not based on empirical results, but rather on entrepreneurial education. people who participate in operating companies have higher levels of education (Robinson, P. B. (1987).

"Giving little or no consideration to the generic shortcomings of demographic study of entrepreneurship, the promising results of research on the relationship between formal education and innovation were accompanied by bold decisions from policy makers to introduce specialist courses in tertiary institutions to foster entrepreneurship. Entrepreneurship education program is tailored arousing the entrepreneurial desire of graduates and produce graduates who will be job creators rather than job seekers. The importance of entrepreneurship education is stated by government agencies' policies worldwide. According to reports by the OECD (2010) "Entrepreneurship education must be at the core of any nation's education policy". The roles of entrepreneurship education programs have been acknowledged in Scandinavian countries, these countries have entrepreneurship education in their policies (Nurmi \& Paasio, 2007). Scholars have given details explanation as to the extent to which the positive role of entrepreneurship can contribute to economic development. However, they also emphasized the need to document the role of entrepreneurship education in entrepreneurial development (Kourilsky \& Walstad 
1998).

According to Gorman, Hanlon \& King (1997), research on the nature, impact and impact of business education has been carried out in several contexts. Some studies mainly describe entrepreneurship courses, discussing teaching methods for an effective entrepreneurial education (Bae, Qian, Miao \& Fiet, 2014) or investigating the impact of business education programs on participants and non-participants of these programs. In the past, when policy makers were still curious about entrepreneurship education research, series of methodologies were used to determine the effect of entrepreneurship education program (EEP). Some research studies describe courses and trends in entrepreneurship education, or investigating the extent to which the course has impacted on participants. They do this by comparing participants of entrepreneurial courses with non-participants.

According to Gibb (1993), some of the early studies as to the interrelationships among entrepreneurship education, entrepreneurial intentions and behavior provided weak support. However, more recent studies that use more advanced research designs and analytical methods provide more encouraging results (Krueger \& Brazeal, 1994; Robinson \& Haynes, 1991) It has been shown that participating companies and business education are related to the development of new risks. Some studies show that the enrollment of business education in participating universities and students can encourage the new entrepreneurship.

From all the different research and empirical studies carried out on entrepreneurship education, only three empirical studies have had a great impact on the field. According to a report by Pterman \& Kennedy (2003), "Entrepreneurship education affects entrepreneurial intentions of high school students. This study was carried out in 17 schools located in Australia and 109 students were nominated to participate in entrepreneurial program and 11 students were placed in a control group. The result of this survey was amazing as participants with weak entrepreneurial skills before participating in the program experienced a stronger positive mindset than participants who are very passionate about the field. Also Souitaris, Zerbinati \& Al-Laham, (2007b) "the entrepreneurship education program was directed at developing stronger entrepreneurship intentions, in their case through a semester-long program at two major European universities". Students that participated in the program have a better attitude to entrepreneurship and entrepreneurial Initiative, especially science and engineering students. This finding is also reflected in the work of Oosterbeek, Praag, \& Ijsselstein (2010) that investigated the impact of entrepreneurship education in a compulsory course using a difference-in-differences framework and affirmed the positive relationship between entrepreneurship education and entrepreneurial intentions of the students.

\section{Hypothesis Development}

\section{Entrepreneurship Education and Entrepreneurial Intentions}

Jones and English (2004) defined entrepreneurship education as "a way of developing individuals' ability to recognize business opportunities and cash on them, besides developing self-esteem, knowledge, and skills in commencing a business venture in the event of risk". This definition lay emphasis on action based knowledge, encourages practical learning 
(learning by doing it), Problem solving type, project-based, creative and above all allows peers evaluation. They further ascertain that entrepreneurship education learning process helps to develop enterprising skill behaviors that are needed to create and manage business ventures.

Politis (2005) developed a framework that take into consideration three important factors necessary in the process of entrepreneurial learning - transformation process, entrepreneurs' career experience, and entrepreneurial knowledge. These factors are prerequisites for recognizing entrepreneurial opportunities. In other words, without a thorough knowledge of them, the tendency of an entrepreneur recognizing an opportunity will be very slim.

From the various definitions of entrepreneurship education, it can be deduced that they all point down to effectiveness. This study however conceptualize effective entrepreneurship education as platform through which individuals are exposed to practical business knowledge, build self-confidence and develop skills in order to succeed in running business venture (Wilson, Kickul \& Marlino (2007). Hence, perceived effective entrepreneurship education is the perception on the effectiveness of the knowledge acquired about entrepreneurship (Souitaris, Zerbinati \& Al-Laham, (2007b). According to Liñán, Rodríguez-Cohard, and Rueda-Cantuche (2011), entrepreneurial training should consider, in addition to increasing perceived feasibility and desirability, the development of the business venture after the initial establishment. Their studies pointed out to the fact that these can be achieved via creating general awareness, encouraging creativity and recognition of business opportunity as well as getting recent and updated information about happenings in the business environment.

For Instance, Souitaris, Zerbinati \& Al-Laham, (2007b) showed that the entrepreneurship program increased attitudes and the overall entrepreneurial intention and that inspiration is the most dominant benefit derived from the program. The findings lay emphasis on the practice of teaching entrepreneurship and suggested that in order to achieve the expected result, entrepreneurship programs should offer courses with modules or syllabus that encourage business plan writing that can stand the test of time with great ideas as well as motivating and inspirational talk on business success and networking.

Meanwhile, Dohse and Walter (2010) examined the extent of entrepreneurship education within the university departments that influenced students' entrepreneurial intentions. According to them, the effect of entrepreneurship education will be a function of delivery mode, regional context and role models influence. The result unveiled how actives mode of entrepreneurship education affects the intentions and attitude of students. It further shows that the influence of the reflective modes is a function of the environment the students reside. In the nutshell, the study provided the implication for delivering entrepreneurship education. In addition, Nabi and Linan (2011) identified and clarified issues pertaining to graduates in the developing world. They conclusively emphasised on entrepreneurship education in particular as a key instrument to help promote entrepreneurial activity. In a related study, Lange, Marram, Jawahar, Yong, and Bygrave (2011) indicated that writing of business plan also highly influenced students' intentions and eventual behaviour. In general, Lekoko, Rankhumise, and Ras (2012) showed that effective entrepreneurship education is important in 
driving students' entrepreneurial intention.

Furthermore, Gerba (2012) asserted that students who had been taught entrepreneurship education had better entrepreneurial intention over students who had not taken entrepreneurship course. In the same context, Muofhe and Du Toit (2011) indicated that entrepreneurship students were more disposed to entrepreneurial intentions than nonentrepreneurship students; they also found a direct relationship between entrepreneurship education and entrepreneurial intentions. Likewise, results obtained in a study carried out by Kolvereid and Moen (1997) indicated that graduates who enrolled the entrepreneurship course as major were more likely to start new businesses and had stronger entrepreneurial intentions than the others.

Moreover, the study of Peterman \& Kennedy, (2003) provided empirical evidence to support exposure to entrepreneurship education as an additional contributing variable in entrepreneurial intentions models. Other studies revealed considerable changes in attitudes in response to entrepreneurship education (Byabashaija \& Katono, 2011). The findings from this study presented useful information that for policy makers and inspire curiosity in the mind of researchers. This will make them to further research on the effectiveness of courses in entrepreneurship education and the mechanism that can improves its effectiveness.

Zainuddin and Rejab (2010) believed that specialized entrepreneurship education can help to increase the efficiency of entrepreneurial self-efficacy and inculcate the spirit of self-employment intention. This will increase the employability value in the long term. This study postulated that the act of introducing specific entrepreneurship education targeted and suitable to a particular group could yield desired results. The other studies that aimed at evaluating entrepreneurship education program simply pointed out to the increasing interest among researchers and policy makers to determine the effectiveness of such program with the basic aim of employing best practices in delivering entrepreneurship education

In the developing countries, for example, rarely researches are available that relates entrepreneurship education and entrepreneurial intentions (Nabi \&Liñán, 2011). Effective entrepreneurship education has seemed to be the major concern among stakeholders, especially policy makers, university authorities, and trainers; hence, the continuous evaluation of the program by various researchers, including the government to help in improving its development and implementation. Consequently, the recommendation on the need for future studies to examine the relationship between effective entrepreneurship education and entrepreneurial intention (Gaddam, 2008; Solesvik, Westhead, Kolvereid, \& Matlay (2012) must be looked into. In an attempt to determine the relationship between perceived effective entrepreneurship education and entrepreneurial intention of university students, the following hypothesis has been proposed by the study.

H1: Participation in entrepreneurship education program positively affects the entrepreneurial intentions of individuals

\section{Data Collection}

For data collection, this study adopted positivist paradigm of logic. Data were collected from 
the university students who were in the last year of their study program and convenient sampling technique was utilized to gather data.

\section{Research Instrument and Measurement Scale}

\section{Effective Entrepreneurship Education}

Perceived effective entrepreneurship education is operationalized in this study as the perception of students on the extent to which entrepreneurship education acquired increases their understanding of why entrepreneurs act, what need to be done, how to start a venture, who to know and when to act in the entrepreneurship process. This study adopted 5 items to measure perception of the effectiveness of entrepreneurship education from Souitaris, Zerbinati \& Al-Laham, (2007b). These items were initially developed as a perceptual scale to measure learning from an entrepreneurship program. The choice of perceptual measure of education had been in line with the suggestion that perception of environment can have a strong prediction on entrepreneurial activities than the actual situation (Zahra, 1993). The students were asked five questions to respond to, based on a 7-point Likert scale of $(1=$ not at all, 7=to a large extent). Examples of the questions are; "to what extent did the entrepreneurship education increase your understanding of the attitudes, values, and motivation of entrepreneurs"?, "to what extent did the entrepreneurship education increase your understanding of the actions someone has to take in order to start a business"?, "to what extent did the entrepreneurship education enhance your practical management skills in order to start a business", etc. The authors reported a reliability of $\alpha=0.71$ and the construct was found to be unidimensional, all items were loaded on a single factor. In addition, the authors validated their measure by correlating the scores on the perceptual scale with the grades for the entrepreneurship courses. They found positive and significant correlation $(r=0.71$, $\mathrm{p}<0.001$ ), hence supporting the validity of the learning measure.

\section{Entrepreneurial Intention}

Entrepreneurial intention as used in this study indicates the degree of effort a student is will to make in order to carryout future entrepreneurial behavior. The 6 items that measured entrepreneurial intention were obtained from Linan and Chen (2009). Some of the sample items are: "I am ready to do anything to be an entrepreneur", "I am determined to create a firm in the future", etc. The items were measured on a rate of 7 - point Likert scale $(1=$ total disagreement, $7=$ total agreement).

\section{Data Analysis}

This study used structural equation modeling technique to test the hypothesis. The Partial Least Squares technique is a powerful component-based method widely used in prior studies (Farrukh, Khan, et al., 2017; Farrukh, Chong, Mansori, \& Ravan Ramzani, 2017; Farrukh, Wei Ying, \& Abdallah Ahmed, 2016; Farrukh, Ying, \& Mansori, 2016, 2017; Riaz, Farrukh, Rehman, \& Ishaque, 2016; Shahzad, Farrukh, Kanwal, \& Sakib, 2018). martPLS version 3 was used to run SEM. SEM is a two-step process. 
Table 1. Measurement Model Evaluation

\begin{tabular}{lclcc}
\hline Construct & Indicators & Loadings & $\begin{array}{c}\text { Composite } \\
\text { Reliability }\end{array}$ & AVE \\
\hline Entrepreneurial Intention & EI2 & .777 & .941 & .762 \\
EI3 & & .898 & & \\
EI4 & .913 & & \\
EI5 & .895 & & \\
EI6 & .872 & & .621 \\
Perceived Effective Entrepreneurship & .785 & .891 & \\
PEEE1 & & & \\
PEEE2 & .806 & & \\
PEEE3 & .804 & & \\
PEEE4 & .750 & & \\
PEEE5 & & .793 & & \\
\hline
\end{tabular}

Table 2. Discriminant validity

\begin{tabular}{lrr}
\hline Construct & $\mathbf{1}$ & $\mathbf{2}$ \\
\hline 1) Entrepreneurial Intention & $\mathbf{. 8 7 3}$ & \\
2) Perceived Effective Entrepreneurship Education & .244 & $\mathbf{. 7 8 8}$ \\
\hline
\end{tabular}

Results from Assessment of Structural Model

Table 3. Results of Path Coefficients

\begin{tabular}{llllll}
\hline Hypothesis & Hypothesis Path & $\begin{array}{l}\text { Path } \\
\text { Coefficient }\end{array}$ & $\begin{array}{l}\text { Standard } \\
\text { Error }\end{array}$ & $\begin{array}{l}\text { T } \\
\text { Value }\end{array}$ & $\begin{array}{l}\text { P } \\
\text { Value }\end{array}$ \\
\hline H4 (+) & PEEE -> EI & -.130 & .044 & 2.970 & .002 \\
\hline
\end{tabular}

*: Significant at $\mathrm{P}<0.01$

\section{Discussion}

The empirical findings showed that perceived effective entrepreneurship education is significant but relate to entrepreneurial intentions negatively $(\beta=-.130)$, thus, signifying that the students' perception of the effectiveness of entrepreneurship education significantly decreased their intention to venture into entrepreneurship. In another sense, it says that their perception of the entrepreneurship program demotivate their desire to be an entrepreneur as a reliable profession. Perhaps, this finding could be attributed to the nature of handling and delivering this program by the various Pakistani universities, as the influence of entrepreneurship education on entrepreneurial intention could depend on the mode of delivery (Dohse\& Walter, 2010). This study contend that issue related to traditional approaches to learning and teaching, to quality of the program and student attitudes, can conspire to frustrate a truly innovative approach to delivering an effective entrepreneurship education. The only way students can learn to demonstrate their entrepreneurial capabilities is through effective entrepreneurship education. This study ascertain that entrepreneurship education's delivery can play a great role in transforming students into entrepreneurs. Some of these things may not be taught in classroom or found in any textbooks, game simulations and traditional forms of assessment. What is really needed for proper entrepreneurial development is a guided self-discovery approach to learning. This approach will enable 
students to learn by doing and assuming the role of a real entrepreneur. However, programs like this requires series of guidance and coaching from educators, seasoned entrepreneurs, as they are in better position to teach the students how to make better sense of their experience.

This whole process requires sacrifices from educators and students. The students should be willing to get out of their comfort zone while educators should use mentoring and coaching approach to inculcating entrepreneurial behavior, skills and attitudes in students. Also it is strongly advice that institutions introduce high quality courses that are not conventional teaching method. Risk taking should definitely be part of the course to be introduced.

In addition, the results indicated that there is no direct correlation between entrepreneurial intention and entrepreneurship education; entrepreneurship education will be understood better if there is any meaningful impact on other intention related variables. This can be substantiated by the study carried out by Zainuddin and Rejab (2010), which showed that the students did not perceive self-actualisation and expectations of their lecturers in becoming self-employed as influential, but believed that specialized entrepreneurship education contributed to increased entrepreneurial self-efficacy, and subsequently, towards their self-employment intention. Again, studies in the developing countries, especially in Africa, indicated that effective entrepreneurship education is yet to be developed (e.g. Nabi \&Liñán, 2011; Lekoko et al., 2012) to successfully provide students with entrepreneurial skills and competencies that would assist them in choosing entrepreneurship as a career option

\section{Contribution}

This study offers relevant contributions that provide perfect understanding of the antecedents of entrepreneurial intentions among Pakistani university students. This will enable all relevant stakeholders responsible for entrepreneurship development to have a better picture of how EI is formed and the mindset of potential venture initiators. It further shows the role entrepreneurship education plays in driving the individual personality traits to increase entrepreneurial intention if the program is made effective. This will instigate government, policy makers and other relevant stakeholders to direct resources on young adults who tend to form entrepreneurial intentions and subsequently be involved in entrepreneurial behavior. It is important to have a good knowledge of the determinants of entrepreneurial intention. This will help to support entrepreneurial training and discover best ways to mould EI and inculcate the spirit of entrepreneurship on new business start-up. This study also seeks to encourage universities to play their roles in various capacities so as to actualize the goal of initiating and encouraging business start-up by young graduates. . Hence, some scholars have pointed out that the challenges for the developing world is to develop graduate entrepreneurs and to provide suitable and supportive environments that will contribute to the growth of entrepreneurship (Nabi \&Liñán, 2011).

However, the findings of this study provided certain clues that can be employed for future design of entrepreneurship education; (1) it showed the need for educators to design training program that would help in developing enterprising behaviors, characteristics, and skills necessary for business start-up. Finally, this study should be of interest to the groups of researchers, teachers, and supporters of entrepreneurship because it clarifies the interplay 
between the underexplored concepts of the effectiveness of entrepreneurship education, in the formation of overall entrepreneurial intention.

\section{References}

Autio, E., \& Acs, Z. (2010). Intellectual property protection and the formation of entrepreneurial growth aspirations. Strategic Entrepreneurship Journal, 4, 234-251. https://doi.org/10.1002/sej.93

Bae, T. J., Qian, S., Miao, C., \& Fiet, J. O. (2014). The Relationship Between Entrepreneurship Education and Entrepreneurial Intentions: A Meta-Analytic Review. Entrepreneurship Theory and Practice, 38(2), 217-254. https://doi.org/10.1111/etap.12095

Brown, R. B. (2000). Contemplating the Emotional Component of Learning The Emotions and Feelings Involved when Undertaking an MBA. Management Learning, 31(3), 275-293. https://doi.org/10.1177/1350507600313001

Byabashaija, W., \& Katono, I. (2011). The impact of college entrepreneurial education on entrepreneurial attitudes and intention to start a business in Uganda. Journal of Developmental Entrepreneurship, 16, 127-144. https://doi.org/10.1142/S1084946711001768

Coduras, A., Urbano, D., Rojas, Á., \& Martínez, S. (2008). The relationship between university supports to entrepreneurship with entrepreneurial activity in Spain: A GEM data based analysis. International Advances in Economic Research, 14, 395-406. https://doi.org/10.1007/s11294-008-9173-8

Dohse, D., \& Walter, S. G. (2010). The role of entrepreneurship education and regional context in forming entrepreneurial intentions: Working Papers 2010/18, Institut d'Economia de Barcelona (IEB).

Farrukh, M., Chong, W. Y., Mansori, S., \& Ravan Ramzani, S. (2017). Intrapreneurial behaviour: the role of organizational commitment. World Journal of Entrepreneurship, Management and Sustainable Development, 13(3), 243-256. https://doi.org/10.1108/WJEMSD-03-2017-0016

Farrukh, M., Khan, A. A., Khan, A. A., Shahid, K. M., Ravan Ramzani, S., \& Soladoye, B. S. A. (2017). Entrepreneurial intentions: the role of family factors, personality traits and self-efficacy. World Journal of Entrepreneurship, Management and Sustainable Development, 13(4), 303-317. https://doi.org/10.1108/WJEMSD-03-2017-0018

Farrukh, M., Wei, Y. C., \& Abdallah, A. N. O. (2016). Organizational commitment: Does religiosity matter? Cogent Business \& Management, 3(1), 1-10. https://doi.org/10.1080/23311975.2016.1239300

Farrukh, M., Ying, C. W., \& Mansori, S. (2017). Organizational commitment: an empirical analysis of personality traits. Journal of Work-Applied Management, 9(1), 18-34. https://doi.org/10.1108/JWAM-12-2016-0026

Farrukh, M., Ying, C., \& Mansori, S. (2016). Intrapreneurial behavior: an empirical 
investigation of personality traits Research issue. Management \& Marketing. Challenges for the Knowledge Society, 11(4), 597-609. https://doi.org/10.1515/mmcks-2016-0018.Introduction.

Fayolle, A., \& Gailly, B. (2004). Using the theory of planned behaviour to assess entrepreneurship teaching programs: A first experimentation. Paper presented at the IntEnt2004 Conference, Naples (Italy).

Gaddam, S. (2008). Identifying the Relayionship Between Behavioral Motives and Entrepreneurial Intentions: An Empirical Study Based Participations of Business Management Students. The Icfaian Journal of Management Research, 7, 35, 5.

Gartner, W. B. (1988). Who Is an Entrepreneur? Is the Wrong Question American Journal of Small Business, 12, 11-32. https://doi.org/10.1177/104225878801200401

Gerba, D. T. (2012). Impact of entrepreneurship education on entrepreneurial intentions of business and engineering students in Ethiopia. African Journal of Economic and Management Studies, 3, 258-277. https://doi.org/10.1108/20400701211265036

Gibb, A. (2002a). In pursuit of a new 'enterprise'and 'entrepreneurship'paradigm for learning: creative destruction, new values, new ways of doing things and new combinations of knowledge. International Journal of Management Reviews, 4, 233- 269. https://doi.org/10.1111/1468-2370.00086

Gibb, A. A. (1993). Enterprise Culture and Education Understanding Enterprise Education and Its Links with Small Business, Entrepreneurship and Wider Educational Goals. International Small Business Journal, 11(3), 11-34. https://doi.org/10.1177/026624269301100301

Gorman, G., Hanlon, D., \& King, W. (1997). Some research perspectives on entrepreneurship education, enterprise education and education for small business management: A ten-year literature review. International Small Business Journal, 15(3), 56-77. https://doi.org/10.1177/0266242697153004

Heinonen, J., \& Poikkijoki, S. A. (2006). An entrepreneurial-directed approach to entrepreneurship education: Mission impossible? Journal of Management Development, 25(1), 80-94. https://doi.org/10.1108/02621710610637981

Johannisson, B., Halvarsson, D., \& Lōvstal, E. (2001). Stimulating and fostering entrepreneurship through university training-learning within an organizing context. In R. H. Brockhaus, G. E. Hills, H. Klandt \& H. P. Welsch (Eds.), Entrepreneurship Education-A Global View. (pp. 318-340). Aldeshot, UK: Ashgate Publishing Limited.

Jones, C., \& English, J. (2004). A contemporary approach to entrepreneurship education.

Katz, J. A. (2003). The chronology and intellectual trajectory of American entrepreneurship education. Journal of Business Venturing, 18, 283-300. https://doi.org/10.1016/S0883-9026(02)00098-8

Keat, O. Y., Selvarajah, C., \& Meyer, D. (2011). Inclination towards entrepreneurship among 
university students: An empirical study of Malaysian university students. International Journal of Business and Social Science, 2, 206-220.

Koe, W. L., Sa'ari, J. R., Majid, I. A., \& Ismail, K. (2012). Determinants of entrepreneurial intention among millennial generation. Procedia - Social and Behavioral Sciences, 40, 197-208. https://doi.org/10.1016/j.sbspro.2012.03.181

Kolvereid, L., \& Moen, Ø. (1997). Entrepreneurship among business graduates: Does a major in entrepreneurship make a difference? Journal of European Industrial Training, 21, 154-160. https://doi.org/10.1108/03090599710171404

Kourilsky, M. L., \& Walstad, W. B. (1998). Entrepreneurship and female youth: knowledge, attitudes, gender differences, and educational practices. Journal of Business Venturing, 13(1), 77-88. https://doi.org/10.1016/S0883-9026(97)00032-3

Krueger, N. F., \& Brazeal, D. V. (1994). Entrepreneurial potential and potential entrepreneurs. Entrepreneurship Theory and Practice, 18, 91-91. https://doi.org/10.1177/104225879401800307

Kuratko, D. F. (2003). Entrepreneurship education: Emerging trends and challenges for the 21 st century. White Paper, US Association of Small Business Education.

Kuratko, D. F. (2005). The emergence of entrepreneurship education: development, trends, and challenges. Entrepreneurship Theory and Practice, 29, 577-598. https://doi.org/10.1111/j.1540-6520.2005.00099.x

Lange, J. E., Marram, E., Jawahar, A. S., Yong, W., \& Bygrave, W. (2011). Does an entrepreneurship education have lasting value? A study of careers of 4,000 alumni. Frontiers of entrepreneurship research, 31(6), 2.

Lekoko, M., Rankhumise, E., \& Ras, P. (2012). The effectiveness of entrepreneurship education: What matters most? African Journal of Business Management, 6, 12023- 12033. https://doi.org/10.5897/AJBMx12.001

Lin, E., Lin, T. M., \& Lin, B. W. (2010). New high-tech venturing as process of resource $\begin{array}{llll}\text { accumulation. Management } \quad \text { Decision, } & \text { 48, }\end{array}$ https://doi.org/10.1108/00251741011076762

Liñán, F., Rodríguez, C. J. C., \& Rueda, C. J. M. (2011). Factors affecting entrepreneurial intention levels: a role for education. International Entrepreneurship and Management Journal, 7, 195-218. https://doi.org/10.1007/s11365-010-0154-Z

Muofhe, N. J., \& Du Toit, W. F. (2011). Entrepreneurial education's and entrepreneurial role models' influence on career choice. SA Journal of Human Resource Management, 9(1), 1-15. https://doi.org/10.4102/sajhrm.v9i1.345

Nabi, G., \& Liñán, F. (2011). Graduate entrepreneurship in the developing world: Intentions, education and development. Education + Training, 53, 325-334. https://doi.org/10.1108/00400911111147668 
Naffziger, D. W., Hornsby, J. S., \& Kuratko, D. F. (1994). A proposed research model of entrepreneurial motivation. Entrepreneurship Theory and Practice, 18, 29-42. https://doi.org/10.1177/104225879401800303

Nurmi, P., \& Paasio, K. (2007). Entrepreneurship in Finnish universities. Education+ Training, 49(1), 56-65. https://doi.org/10.1108/00400910710729884

O'Connor, A. (2013). A conceptual framework for entrepreneurship education policy: Meeting government and economic purposes. Journal of Business Venturing, 28(4), 546-563. https://doi.org/10.1016/j.jbusvent.2012.07.003

OECD. (2010). University entrepreneurship support: Policy issues, good practices and recommendations. Working Paper: OECD Local Economic and Employment Development (LEED)

Oosterbeek, H., Van Praag, M., \& Ijsselstein, A. (2010). The impact of entrepreneurship education on entrepreneurship skills and motivation. European economic review, 54(3), 442-454. https://doi.org/10.1016/j.euroecorev.2009.08.002

Otsuki, M. (2002). SMEs supporting systems in Saudi Arabia. speech, October, 15.

Peterman, N. E., \& Kennedy, J. (2003). Enterprise education: Influencing students' perceptions of entrepreneurship. Entrepreneurship Theory and Practice, 28, 129- 144. https://doi.org/10.1046/j.1540-6520.2003.00035.x

Politis, D. (2005). The process of entrepreneurial learning: A conceptual framework.

Riaz, Q., Farrukh, M., Rehman, S. U., \& Ishaque, A. (2016). Religion and entrepreneurial intentions: an empirical investigation. International Journal of Advanced and Applied Sciences, 3(9), 31-36. https://doi.org/10.21833/ijaas.2016.09.006

Robinson, P. B. (1987). Prediction of entrepreneurship based on an attitude consisency model. Unpublished doctoral dissertation, Brigham Young University.

Robinson, P., \& Haynes, M. (1991). Entrepreneurship education in America's major universities. Entrepreneurship Theory and Practice, 15(3), 41-52. https://doi.org/10.1177/104225879101500304

Runco, M. A. (2004). Everyone Has Creative Potential. In R. J. Sternberg, E. L. Grigorenko \& J. L. Singer (Eds.), Creativity: From potential to realization (pp. 21-30). Washington, DC: American Psychological Association. https://doi.org/10.1037/10692-002

Schumpeter, J. A. (1951). Change and the entrepreneur. In R. V. Clemence (Ed.), Essays of JA Schumpeter. Reading, MA: Addison-Wesley.

Shahzad, I. A., Farrukh, M., Kanwal, N., \& Sakib, A. (2018). Decision-making participation eulogizes probability of behavioral output; job satisfaction, and employee performance (evidence from professionals having low and high levels of perceived organizational support). World Journal of Entrepreneurship, Management and Sustainable Development. https://doi.org/10.1108/WJEMSD-01-2018-0006 
Shaikh, D. M. (2012). Students intention towards entrepreneurship: A review of empirical studies. ZENITH, 2, 165-170.

Shook, C. L., \& Bratianu, C. (2010). Entrepreneurial intent in a transitional economy: An application of the theory of planned behavior to Romanian students. International Entrepreneurship and Management Journal, 6, 231-247. https://doi.org/10.1007/s11365-008-0091-2

Solesvik, M. Z., Westhead, P., Kolvereid, L., \& Matlay, H. (2012). Student intentions to become self-employed: The Ukrainian context. Journal of Small Business and Enterprise Development, 19, 441-460. https://doi.org/10.1108/14626001211250153

Souitaris, V., Zerbinati, S., \& Al-Laham, A. (2007b). Do entrepreneurship programmes raise entrepreneurial intention of science and engineering students? The effect of learning, inspiration and resources. Journal of Business Venturing, 22, 566-591. https://doi.org/10.1016/j.jbusvent.2006.05.002

Timmons, J. (1999). New venture creation: Entrepreneur for the 21st century. New York: Irwin Wilson, F., Kickul, J., \& Marlino, D. (2007). Gender, entrepreneurial self efficacy, and entrepreneurial career intentions: Implications for entrepreneurship education. Entrepreneurship Theory and Practice, 31, 387-406. https://doi.org/10.1111/j.1540-6520.2007.00179.x

Zahra, S. A. (1993). A conceptual model of entrepreneurship as firm behavior: A critique and extension. Entrepreneurship Theory and Practice, 17, 5-5. https://doi.org/10.1177/104225879301700401

Zainuddin, M. N., \& Rejab, M. R. M. (2010). Assessing “ME generation's” entrepreneurship degree program in Malaysia. Education + Training, 52, 508- 527. https://doi.org/10.1108/00400911011068469

\section{Copyright Disclaimer}

Copyright for this article is retained by the author(s), with first publication rights granted to the journal.

This is an open-access article distributed under the terms and conditions of the Creative Commons Attribution license (http://creativecommons.org/licenses/by/4.0/). 